\title{
論文
}

\author{
복합재-알루미늄 단일겹침 하이브리드 체결부 강도 특성 실험 연구 \\ 김중진*, 성명수*, 김홍주**, 차봉근**, 권진회***, 최진호***
}

\section{An Experimental Study on the Strength of Composite-to-Aluminum Hybrid Single-lap Joints}

\author{
Jung-Jin Kim*, Myeong-su Seong*, Hong-Joo Kim**, Bong-Keun Cha**, \\ Jin-Hwe Kweon*** and Jin-Ho Choi***
}

\begin{abstract}
Strength and failure of composite-to-aluminum rivetted, bonded, and rivet/bonding hybrid single-lap joints were investigated by experiment. A total of 82 joint specimens were tested with 3 different overlap lengths and 2 types of stacking sequence. FM73m adhesive film and NAS9308-4-03 rivet were used for hybrid joints. While failure loads of the bonded and hybrid joints increased as the overlap length increased, failure loads of the rivetted joints were not affected by the overlap length. Effect of the stacking sequence was not remarkable in the simple bonded or rivetted joints. Failure loads of the hybrid joints, however, showed the maximum of $30 \%$ difference depending on the stacking sequence. Major failure mode of the bonded and hybrid joints was the delamination of the composite adherend and failure mode of riveted joints was the rivet failure with local bearing.

\section{초 록}

본 연구에서는 탄소 복합재와 알루미늄 2024-T3 단일겹침 체결부에 대해, 체결방법을 접 착, 리벳, 리벳/접착 하이브리드의 세 가지로 변화시키면서 체결방법에 따른 파손하중과 파손모드를 실험을 통해 연구하였다. 세 가지 체결방법에 대해 각각 겹침길이 3 가지와 적 층순서 2가지, 총 82개의 시편을 제작하였다. 접착제는 FM73m, 리벳은 NAS9308-4-03을 사 용하였다. 접착 체결과 하이브리드 체결에서는 겹침길이가 커짐에 따라 파손하중이 증가 하였고, 리벳 체결에서는 겹침길이에 따른 파손하중 변화가 나타나지 않았다. 단순 접착 및 리벳 체결부에서는 적층순서에 따른 일관된 경향을 발견하기 어려운 반면, 하이브리드 체결부에서는 인접층의 적층각 차이가 작은 적층판을 사용한 체결부의 파손하중이 높게 나타났다. 접착 체결과 하이브리드 체결의 주된 파손모드는 층간분리이고 리벳 체결은 국 부적 베어링 파손을 동반한 리벳 파손으로 나타났다.
\end{abstract}

Key Words : Joint(체결부), Single-lap(단일겹침), Bonding(접착), Hybrid(하이브리드)

†2008년 5월 23일 접수 2008년 7월 15일 심사완료

\section{I. 서 론}

* 정회원, 경상대학교 기계항공공학부

** 정회원, 한국항공우주산업(주)

**** 정회원, 경상대학교 항공기부품기술연구소 교신저자, E-mail : jhkweon@gnu.kr 경남 진주시 가좌동 900 번지

우수한 기계적 특성과 이상적인 경량구조재로 서 항공우주 분야에 복합재료의 사용이 날로 증 가하고 있다. 또한 항공기와 같은 구조물은 수많 은 부품들을 연결, 조립하기 때문에 체결부 설계 
와 제조 기술의 중요성이 커지고 있다. 구조물에 서 체결부는 잠재적으로 가장 취약한 부분으로 구조물의 건전성을 결정하게 되는 중요한 부분 이다. 최근 체결부를 줄이기 위해 구조물을 일체 형으로 제작하기 위한 연구도 진행되고 있지만 아직은 체결재(fastener) 혹은 접착제(adhesive)를 사용한 체결 방법이 주로 사용되고 있다[1].

구조물의 체결방법으로는 볼트와 리벳 등을 사용하는 기계적 체결(mechanical joint)과 접착 제를 사용한 접착 체결(bonded joint), 그리고 기 계적 체결과 접착 체결방법을 결합하여 사용하는 하이브리드 체결(hybrid joint) 등이 있다.

볼트나 리벳 등을 체결재로 사용하는 기계적 체결방법[2-8]은 구조적 신뢰성이 높고 표면처리 가 필요 없는 반면, 체결재 구멍으로 인해 섬유 의 절단이 불가피하고, 원공 주위에 높은 응력집 중 현상을 유발한다.

접착에 의한 체결방법[9-15]에서는 체결재 구멍 이 필요 없으므로 구멍으로 인한 응력집중현상을 피할 수 있다. 또한 상대적으로 넓은 접착면에 비 교적 균일한 응력을 가지게 된다. 그러나 분해, 조 립과 접착상태의 검사가 어렵고, 접착을 위한 표 면처리 등의 공정이 복잡하다. 또한 온도, 습도 및 환경적 요인에 의하여 체결력이 약화될 수 있다.

접착과 리벳체결 방법을 결합하여 사용하는 하이브리드 체결방식은 구조적으로 가장 안전한 방법이지만, 무게 증가가 가장 큰 단점이다. 또한 정적/동적 설계허용치에 대한 데이터베이스가 부족한 실정이다. 접착/볼트 하이브리드 체결에 대한 연구[16-18]가 이루어진 바 있으나, 실제 항 공기의 체결에 많이 사용되는 리벳과 접착제를 같이 사용한 접착/리벳 하이브리드 체결부에 대 한 연구는 부족한 실정이다.

따라서 본 연구에서는 탄소 복합재와 알루미늄 으로 구성된 단일겹침 체결부에서 접착제와 리벳 을 동시에 사용한 하이브리드 체결방식이 각각을 독립적으로 사용한 접착 혹은 리벳 체결부에 비해 어떤 강도 및 파손특성을 가지는지를 실험으로 연 구하였다. 이를 위해 탄소/에폭시 복합재 (USN125)와 알루미늄(2024-T3)을 사용하여 겹침길 이(3가지)와 적층순서(2가지)를 달리하면서, 단순 접착, 단순리벳, 접착/리벳 하이브리드 체결 시편 총 82 개를 제작하여 정적 강도실험을 수행하였다.

\section{ㅍ. 시 험}

\section{1 시편 제작}

본 연구에서 사용된 단일겹침 체결부 시편의

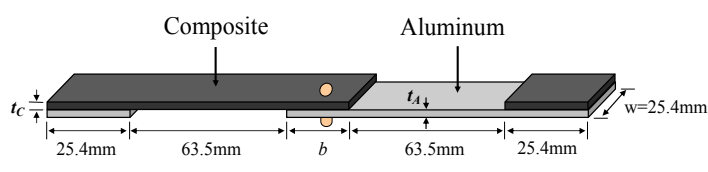

Fig. 1. Configuration of a bond/rivet hybrid joint

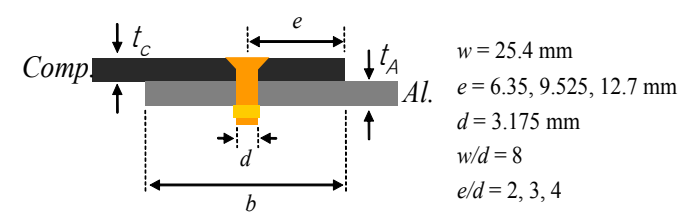

Fig. 2. Cross-section view of a rivet joint

형상은 Fig. 1,2 와 같다. 그림에서 $b$ 는 체결부의 겹침길이로서 $12.7,19.05,25.4 \mathrm{~mm}$ 이다. $\mathrm{t}_{\mathrm{A}}$, $\mathrm{t}_{\mathrm{C}}$ 는 각각 알루미늄과 복합재 모재의 두께를 나타 낸 것으로 $2.0,1.88 \mathrm{~mm}$ 이다.

접착체결 시편 제작을 위해 먼저 성형된 복합 재 적층판과 알루미늄을 접착제로 이차 접착하고 하이브리드 시편은 접착 후 리벳을 체결하였다. 체결부의 두께, 표면처리 방법, 접착제의 종류, 가해준 압력, 체결부에서 겹침길이의 폭과 길이 등은 ASTM D1002-01, D5868-01을 참고하여 결 정하였다.

연구를 위해 사용한 복합재료는 SK케미컬의 USN125(탄소섬유/에폭시 일방향 프리프레그), $\mathrm{GEP} 215$ (유리섬유 평직 프리프레그)이고 알루미 늄은 2024-T3을 사용하였다. 접착제는 Cytec사의 필름 형태 고온경화용 접착제인 $\mathrm{FM} 73 \mathrm{~m}$ 을 사용 하였고 리벳은 NAS9308M-4-03 스테인레스 접시 머리 블라인드 리벳으로 직경이 $3.175 \mathrm{~mm}$ 이다.

실험에 사용된 복합재 모재의 적층순서는 2 가 지로, 첫 번째 적층순서를 가진 적층판 $\mathrm{A}$ 의 적층 순서는 $\quad[( \pm 45) / 45 / 0 /-45 / 90 / 45 / 0 /-45 / 90]_{S}$ 이고 인접층의 적층각을 45 도씩 변하게 하였다. 두 번 째 적층판 $\mathrm{B}$ 의 적층순서는 $[( \pm 45) / 45 /-45 / 0 / 90$ $/ 45 /-45 / 0 / 90]_{S}$ 이고 가능한 한 이웃한 층의 적층 각 차이가 $90^{\circ}$ 가 되도록 하였다. 두 경우 모두 $0^{\circ}, 45^{\circ}, 90^{\circ}$ 층의 상대적 비는 같다. $( \pm 45)$ 는 GEP215 유리섬유 평직 층이다. 사용한 복합재와 알루미늄 및 접착제의 물성치는 Table 1 에 주어 진다.

$\mathrm{FM} 73 \mathrm{~m}$ 의 $\mathrm{S}$ 값은 전단 물성 실험을 통해 구한 값으로 제작사에서 제시한 금속-금속 접착시의 전단강도 $46.1 \mathrm{MPa}$ [19]보다 낮다.

모든 시편은 워터젯(water jet)으로 가공하였다. 워터젯으로 가공된 시편의 전형적인 단면은 Fig. 3에 보인 바와 같다[9]. 
Table 1. Material properties

\begin{tabular}{|c|l|l|}
\hline \multirow{4}{*}{ USN125 } & $\mathrm{E}_{1}=162 \mathrm{GPa}$ & $\mathrm{E}_{2}=9.6 \mathrm{GPa}$ \\
\cline { 2 - 3 } & $\mathrm{G}_{12}=6.1 \mathrm{GPa}$ & $\mathrm{v}_{12}=0.298$ \\
\cline { 2 - 3 } & $\mathrm{X}_{\mathrm{T}}=2652 \mathrm{MPa}$ & $\mathrm{Y}_{\mathrm{T}}=43 \mathrm{MPa}$ \\
\cline { 2 - 3 } & $\mathrm{S}_{12}=94 \mathrm{MPa}$ & $\mathrm{t}=0.105 \mathrm{~mm}$ \\
\hline \hline \multirow{4}{*}{ GEP215 } & $\mathrm{E}_{1}=35.5 \mathrm{GPa}$ & $\mathrm{E}_{3}=17.2 \mathrm{GPa}$ \\
\cline { 2 - 3 } & $\mathrm{G}_{12}=3.7 \mathrm{GPa}$ & $\mathrm{v}_{12}=0.22$ \\
\cline { 2 - 3 } & $\mathrm{v}_{13}=0.32$ & $\mathrm{X}_{\mathrm{T}}=600 \mathrm{MPa}$ \\
\cline { 2 - 3 } & $\mathrm{Z}_{\mathrm{T}}=100 \mathrm{MPa}$ & $\mathrm{S}_{12}=60 \mathrm{MPa}$ \\
\cline { 2 - 3 } & $\mathrm{t}=0.119 \mathrm{~mm}$ & \\
\hline \multirow{2}{*}{ Aluminum } & $\mathrm{E}=73.0 \mathrm{GPa}$ & $\mathrm{G}=26 \mathrm{GPa}$ \\
\cline { 2 - 3 } 2024 & $\mathrm{U}=0.33$ & $\mathrm{X}=434 \mathrm{MPa}$ \\
\cline { 2 - 3 } & $\mathrm{S}=268 \mathrm{MPa}$ & \\
\hline \hline \multirow{2}{*}{ FM73m } & $\mathrm{E}=2.8 \mathrm{GPa}$ & $\mathrm{v}=0.38$ \\
\cline { 2 - 3 } & $\mathrm{S}=34 \mathrm{MPa}$ & \\
\hline
\end{tabular}

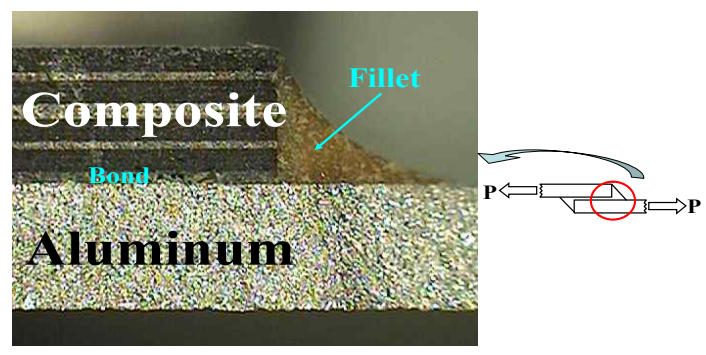

Fig. 3. Microscopic view of bonded specimen after water-jet fabrication

\section{2 체결부 시험}

시험에 사용한 재료시험기는 Instron 5582이고 상온에서 ASTM D1002-01 규격에 따라 분당 1.3 $\mathrm{mm}$ 의 속도로 하중을 가하였다. Fig. 4에서 보인 바와 같이 하이브리드 체결 시편의 시험 중에 발 생하는 체결부의 파손양상을 관찰하기 위해 디지 털 현미경 캠코더를 설치하였다. 본 시험에서는 40 배 배율로 촬영하였다.

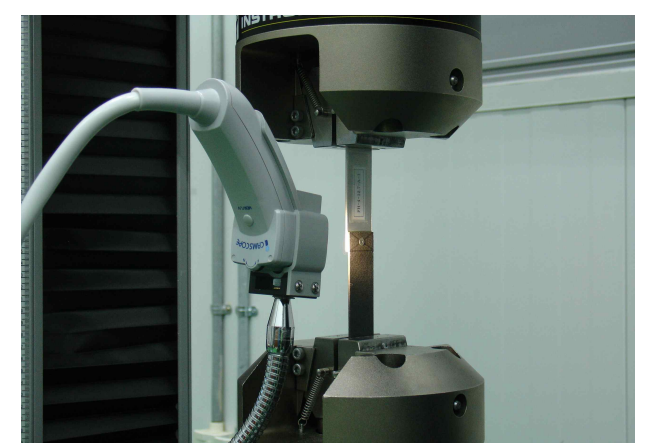

Fig. 4. Set-up for hybrid joint test

\section{III. 결과 및 토론}

\section{1 접착제 체결부}

접착체결 시험을 위해 적층순서 2 가지, 겹침길 이 3 가지 등 총 29 개 시편에 대한 시험을 수행하 였다. 접착 체결부 시편의 전형적인 하중-변위 곡선은 Fig. 5, 6에 제시하였다. 그림에서와 같이 하중-변위 곡선은 대체로 파손 시까지 선형적인 거동을 보인다.

Fig. 7, 8은 필름 접착제 $\mathrm{FM} 73 \mathrm{~m}$ 으로 접착된 단일겹침 체결부의 강도와 파손하중을 비교하여 나타낸 것이다. 일반적으로 체결부의 겹침 길이 가 길어질수록 파손하중이 증가하는 것은 당연한 현상이다. 그러나 파손하중에 접착면적을 나눈 접착강도의 평균값은 반대의 경향을 보인다[9].

Fig. 7에서와 같이 $\mathrm{A}$ 적층판의 경우 접착 체결 부 파손강도는 겹침길이가 $12.7 \mathrm{~mm}$ 일 때 24.45

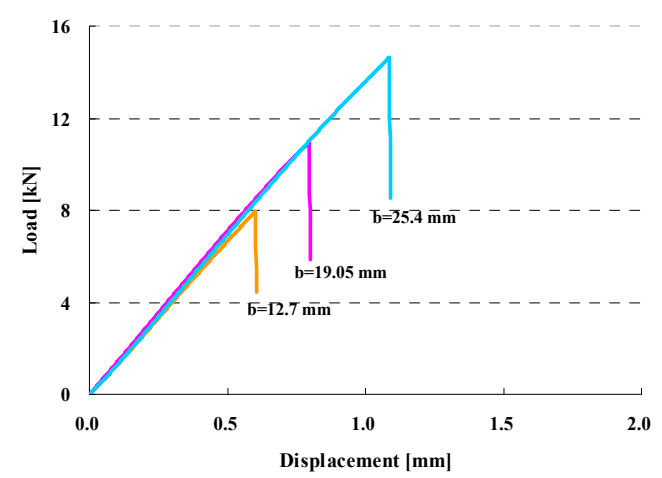

Fig. 5. Load-displacement curves of bonded joints (Laminate A)

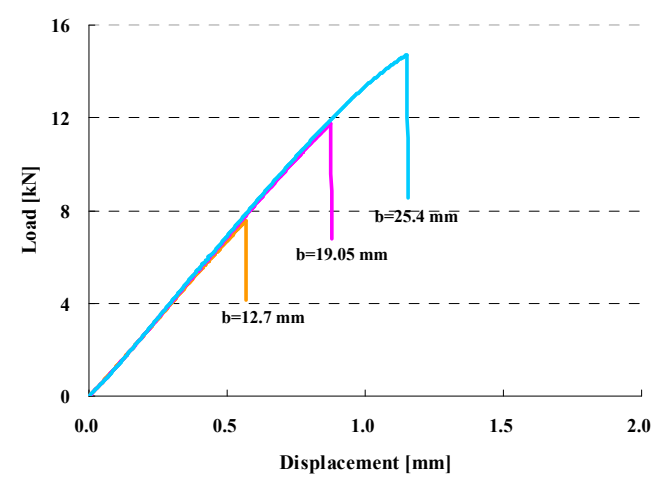

Fig. 6. Load-displacement curves of bonded joints (Laminate B) 


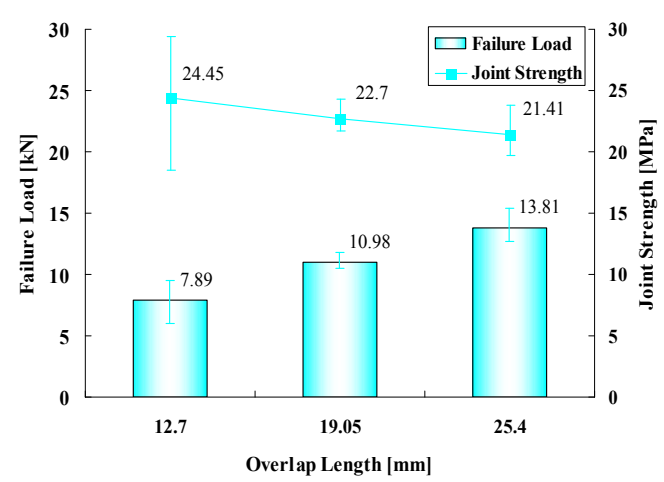

Fig. 7. Failure loads and joint strengths of bonded joints (Laminate A)

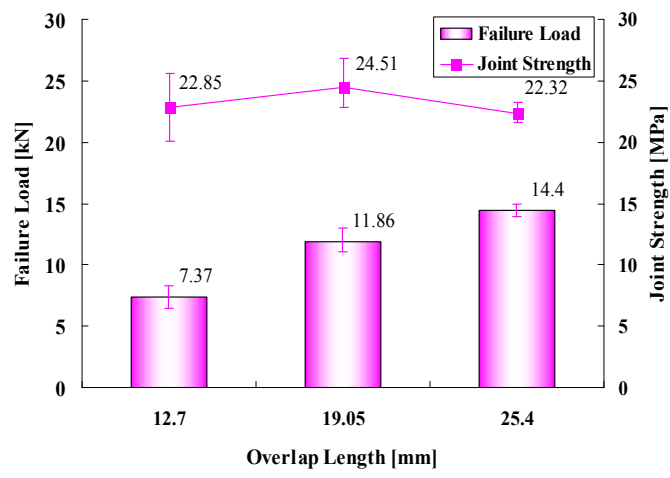

Fig. 8. Failure loads and joint strengths of bonded joints (Laminate B)

$\mathrm{MPa}$ 이다. 19.05와 $25.4 \mathrm{~mm}$ 일 때는 $22.70,21.41$ $\mathrm{MPa}$ 로 $12.7 \mathrm{~mm}$ 대비 각각 $7 \%$ 와 $12 \%$ 낮다. $12.7 \mathrm{~mm}$ 일 때의 파손강도는 실험으로 구한 금속 -금속 단일겹침에서의 접착제 전단강도 $34 \mathrm{MPa}$ 에 비해 $28 \%$ 낮은 값이고, 복합재-복합재 단일겹 침에서의 접착제 전단강도 $23.6 \mathrm{MPa}[10]$ 에 비해 서는 $4 \%$ 높은 값이다.

Fig. 8에 시험결과를 보인 $\mathrm{B}$ 적층판의 경우 접 착 체결 파손강도는 겹침길이가 $12.7 \mathrm{~mm}$ 일 때 $22.85 \mathrm{MPa}$ 이다. $19.05 \mathrm{~mm}$ 일 때는 $24.51 \mathrm{MPa}$ 로 $12.7 \mathrm{~mm}$ 대비 $7 \%$ 높고, $25.4 \mathrm{~mm}$ 일 때 22.32 $\mathrm{MPa}$ 로 $12.7 \mathrm{~mm}$ 대비 $2 \%$ 낮게 나타났다. 12.7 $\mathrm{mm}$ 일 때의 파손강도는 금속-금속 전단강도 34 $\mathrm{MPa}$ 에 비해 $33 \%$ 낮고, 복합재-복합재 전단강도 $23.6 \mathrm{MPa}$ 에 비해 $3 \%$ 낮은 값이다. 적층판 $\mathrm{B}$ 에서 특징적인 현상은 $\mathrm{b}=12.7 \mathrm{~mm}$ 일 때의 파손강도가, 적층판 $\mathrm{A}$ 에서와 달리, 겹침길이가 큰 경우보다 더 작게 나타난다는 것이다. 뒤에서도 언급하겠
지만, 겹침길이 $12.7 \mathrm{~mm}$ 인 시편은 파손양상도 다른 경우와 많이 다르게 나타난다.

적층순서의 관점에서 보면 겹침길이 19.05 와 $25.4 \mathrm{~mm}$ 에서는 적층판 $\mathrm{B}$ 의 강도가 높은 반면, $12.7 \mathrm{~mm}$ 일 때는 적층판 $\mathrm{A}$ 의 강도가 높게 나타 난다. 그러나 전체적으로 동일 겹침길이에서 적 층순서에 따른 차이는 4 8\% 정도로, 실험 데이 터의 분포 범위 내에 있다. 앞에서 밝힌 바와 같 이 적층판 $\mathrm{A}$ 는 이웃한 층의 적층각 차이를 $45^{\circ}$ 로, $\mathrm{B}$ 는 $90^{\circ}$ 로 설계한 것이다. 실험 전, 이웃한 층간 적층각의 차이가 작은 적층판 $\mathrm{A}$ 가 $\mathrm{B}$ 보다 층간분리에 강하고, 이에 따라 체결부 강도가 높 을 것으로 예상했으나, 실험 결과 적층순서에 따 른 특별한 경향을 발견하기는 어려웠다. 이는 적 층순서보다 필렛(fillet) 등과 같은 다른 변수의 효과가 더 크게 작용한 때문인 것으로 판단된다.

Fig. 9는 겹침길이와 적층순서에 따른 파손면 사진을 나타낸 것이다. 시편의 최종 파손은 복합 재 모재의 층간분리가 주를 이루고 있다. 겹침 길이가 $12.7 \mathrm{~mm}$ 시편의 경우, 적층판 $\mathrm{A}$ 를 사용 한 체결부의 주된 파손모드는 Fig. 9(a)에 보인 바와 같이 주로 일방향 단층간에 존재하는 첫 번 째 층간층(interply) 즉 $45^{\circ}$ 층과 $0^{\circ}$ 층 사이에서의 층간분리이다. 부분적으로는 접착제층과 복합재 모재 사이의 계면파손도 나타났다. 이러한 현상 은 겹침길이가 증가하여도 변하지 않았다. 그러 나 동일한 겹침길이에서 적층순서만 바뀐 $\mathrm{Fig}$. 9 (d)의 경우 유리 평직층과 $45^{\circ}$ 일방향 단층, 일 방향 $45^{\circ}$ 층과 $-45^{\circ}$ 층 사이에서 비슷한 크기의 층 간분리가 발생하였다. 적층판 $\mathrm{A}$ 의 경우 Fig. 9(b) 와 9 (c)에 보인 바와 같이 겹침길이가 $19.05,25.4$ $\mathrm{mm}$ 로 증가하여도 겹침길이가 $12.7 \mathrm{~mm}$ 일 경우 에서와 같이 $45^{\circ}$ 층과 $0^{\circ}$ 층 사이에서의 층간분리 가 주된 파손모드로 나타난다. 그러나 적층판 $\mathrm{B}$ 를 사용한 체결부의 경우 Fig. 9(e), 9(f)에 보인 바와 같이 $45^{\circ}$ 층과 $-45^{\circ}$ 층, $-45^{\circ}$ 층과 $0^{\circ}$ 층 사이에 서 큰 층간분리가 발생하였다.

적층순서의 관점에서 보면 전체적으로 적층판 $\mathrm{A}$ 는 주로 $45^{\circ} \%^{\circ}$ 사이에서 파손이 발생하고, 적 층판 $\mathrm{B}$ 는 $45 \%-45^{\circ}$ 사이에서뿐만 아니라 이웃한 층간층에서도 비교적 넓은 층간분리 파손이 발생 한다. 특히 적층판 $\mathrm{B}(12.7 \mathrm{~mm})$ 의 경우에는 첫 번 째 층간층 즉 평직층과 $45^{\circ}$ 층 사이에서 큰 층간 분리가 발생하였는데 이때 접착강도가 상대적으 로 낮게 나타났다.

\section{2 리벳 체결부}

리벳 체결부 강도를 얻기 위해 적층순서 2 가 


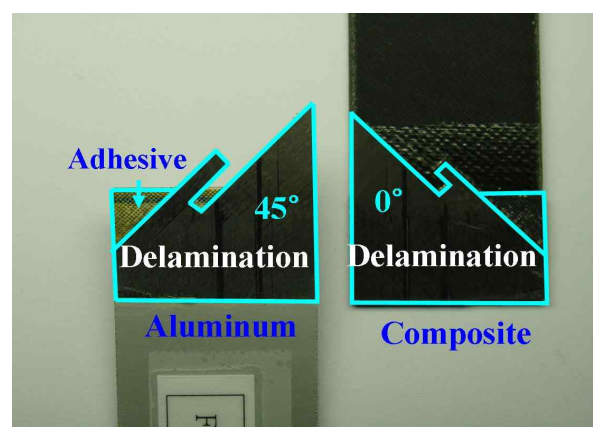

(a) Laminate $A(b=12.7 \mathrm{~mm})$

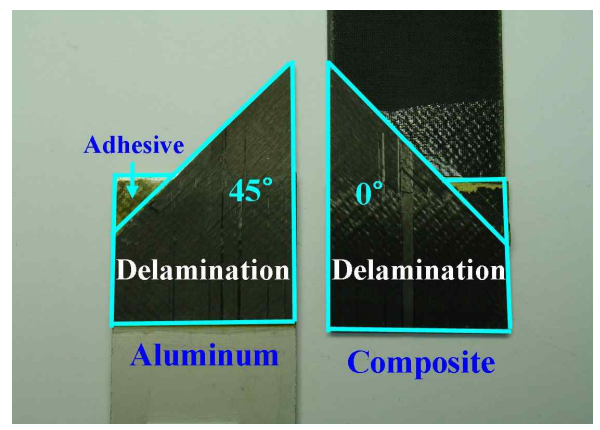

(b) Laminate $A(b=19.05 \mathrm{~mm})$

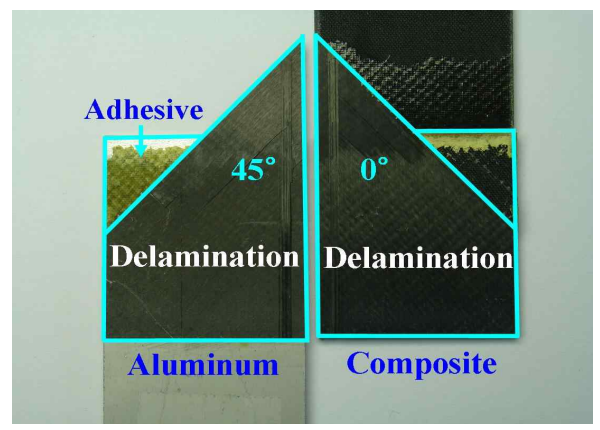

(c) Laminate $A(b=25.4 \mathrm{~mm})$

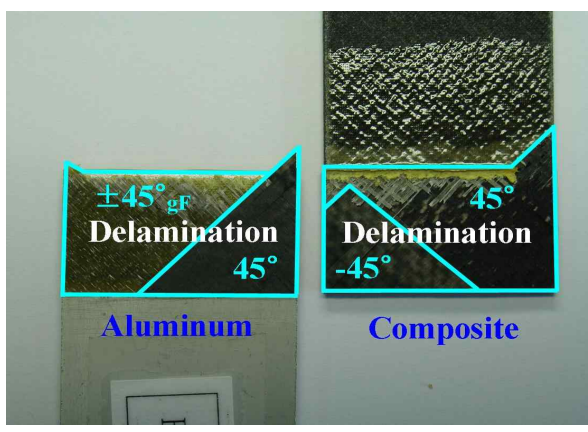

(d) Laminate $B(b=12.7 \mathrm{~mm})$

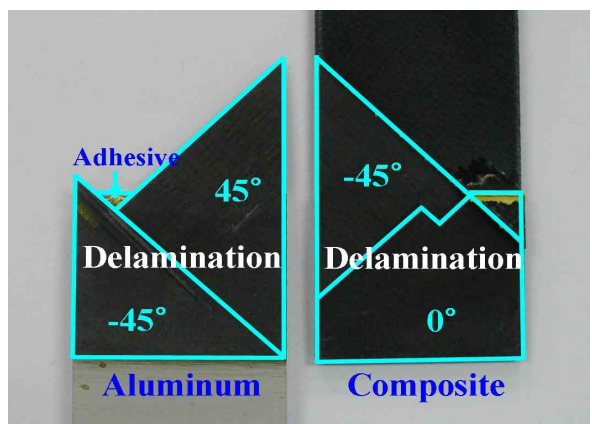

(e) Laminate B (b=19.05 mm)

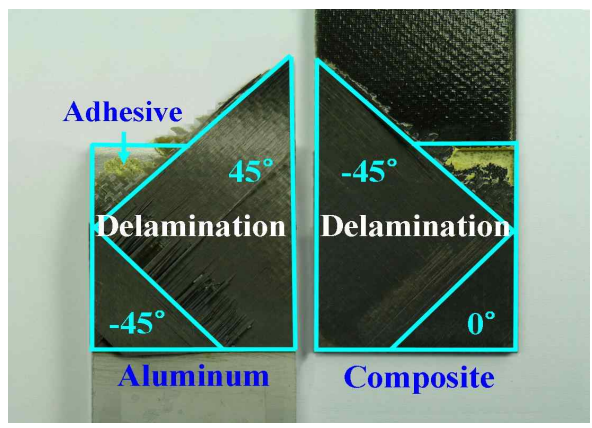

(f) Laminate $B(b=25.4 \mathrm{~mm})$

Fig. 9. Failure modes of bonded joints

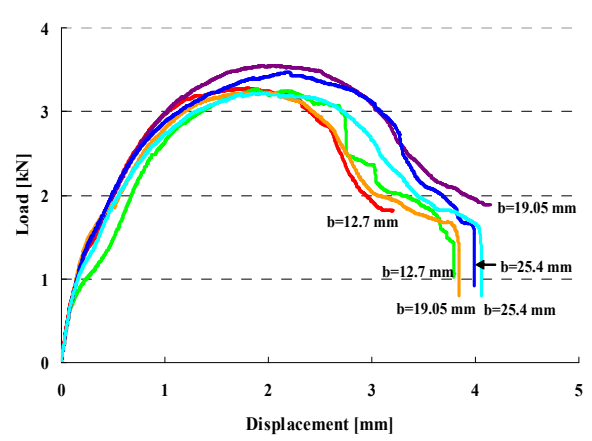

Fig. 10. Load-displacement curves of rivetted joints
지, 겹침길이 3 가지 등 6 경우에 대하여 총 23 개 의 시편에 대한 시험을 수행하였다. Fig. 10에서 파손하중은 하중-변위선도 상의 최대하중으로 정 의하였다.

Fig. 11은 리벳 체결부의 강도 실험 결과를 나 타낸 것이다. 적층순서와 끝단길이비 $(\mathrm{e} / \mathrm{d})$ 에 상 관없이 모두 유사한 하중에서 파손이 발생하였 다. 적층판 $\mathrm{A}$ 의 경우 최대하중은, 겹침길이 12.7 , $19.05,25.4 \mathrm{~mm}$ 일 때 각각 $3.00,3.36,3.36 \mathrm{kN}$ 으로 모두 실험데이터의 분포범위 안에 들어 있 다. 적층판 $\mathrm{B}$ 의 경우에도 파손하중은 $3.38 \mathrm{kN}$ $(12.7 \mathrm{~mm}), 3.17 \mathrm{kN}(19.05 \mathrm{~mm}), 3.30 \mathrm{kN}(25.4$ 


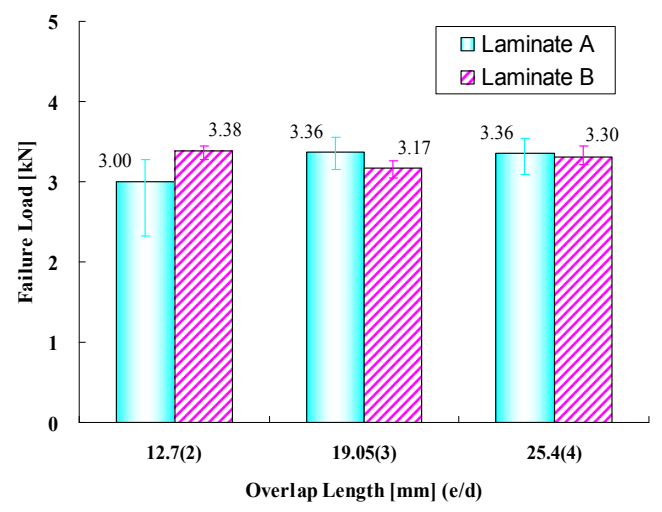

Fig. 11. Failure loads of rivetted joint
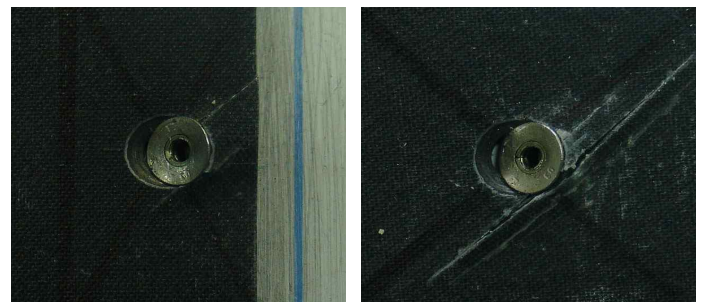

Laminate $A(b=12.7 \mathrm{~mm}) \quad$ Laminate $B(b=25.4 \mathrm{~mm})$

Fig. 12. Failure modes of riveted joints

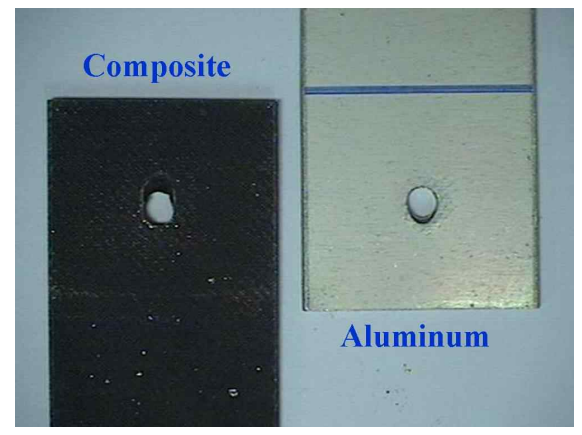

Fig. 13. Adherends after rivet removal

$\mathrm{mm}$ )으로 최대 $6.6 \%$ 이내의 차이를 보이지만 겹 침길이 즉 끝단길이비의 차이보다는 기타 실험상 의 원인에 의한 차이로 보는 것이 타당할 것으로 판단된다. 적층순서의 관점에서도 리벳 체결부 강도의 차이를 발견하기는 어렵다.

Fig. 12에서 보인 바와 같이 겹침길이에 무관 하게 리벳 체결부의 주된 파손모드는 모재의 베 어링 파손을 동반한 리벳 머리 파손으로 나타났 다. 모재의 베어링 파손은 Fig. 13에 보였다. 리 벳 파손은 단일겹침에서 어쩔 수 없이 발생하는

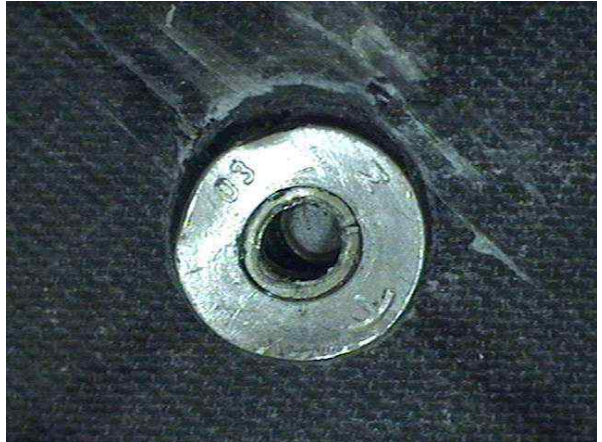

Fig. 14. Rivet (head) failure

하중 작용선 불일치에 의해 리벳이 기울어지면서 Fig. 14에서와 같이 리벳머리 부분과 몸체가 분 리되는 형태로 발생하였다.

\section{3 하이브리드 체결부}

접착/리벳 하이브리드 체결부 시험을 위해 적 층순서 2 가지, 겹침길이 3 가지에 대하여 총 30 개 의 시편을 제작하여 시험을 수행하였다. Fig. 15 와 16 은 하이브리드 체결 시편의 전형적인 하중변위 곡선을 나타낸 것이다.

겹침길이가 $12.7,19.05 \mathrm{~mm}$ 인 하이브리드 체 결 시편의 하중-변위 곡선은 접착체결 시편과 유 사하게 선형적인 거동을 보이고 적층판 $\mathrm{A}$ 를 사 용한 $25.4 \mathrm{~mm}$ 시편의 경우에서는 접착체결 시편 에서 나타나지 않았던 비선형 구간이 나타난다. 파손하중에서 알루미늄 모재의 단면적을 나눈 평 균 인장응력의 관점에서 보면, 겹침길이 12.7 , $19.05,25.4 \mathrm{~mm}$ 일 때 체결부 $\mathrm{A}$ (적층판 $\mathrm{A}$ 를 사용 한 체결부)의 경우 $173,255,376 \mathrm{MPa}$ 이고, 체결 부 $\mathrm{B}$ (적층판 $\mathrm{B}$ 를 사용한 체결부)의 경우 158 , 242, $289 \mathrm{MPa}$ 이다. 알루미늄 2024-T3의 항복응력

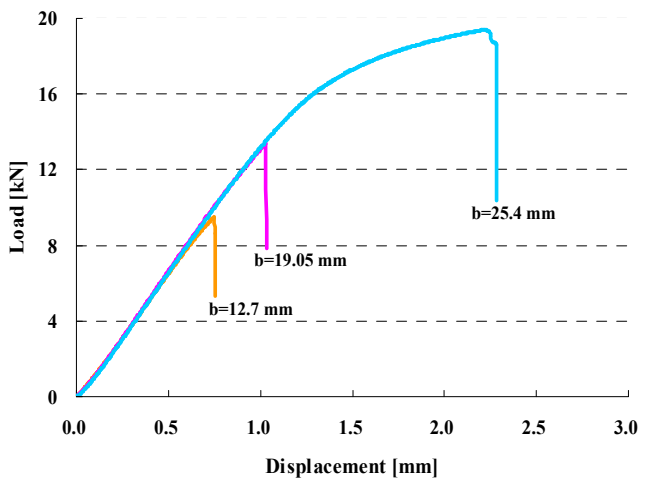

Fig. 15. Load-displacement curves of hybrid joints (Laminate A) 


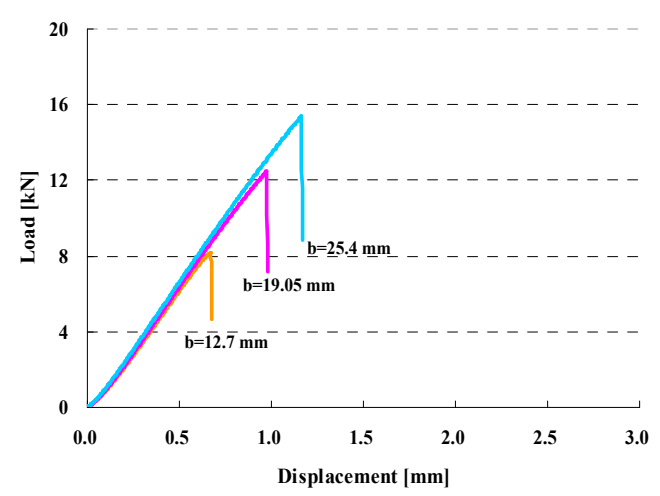

Fig. 16. Load-displacement curves of hybrid joints (Laminate B)

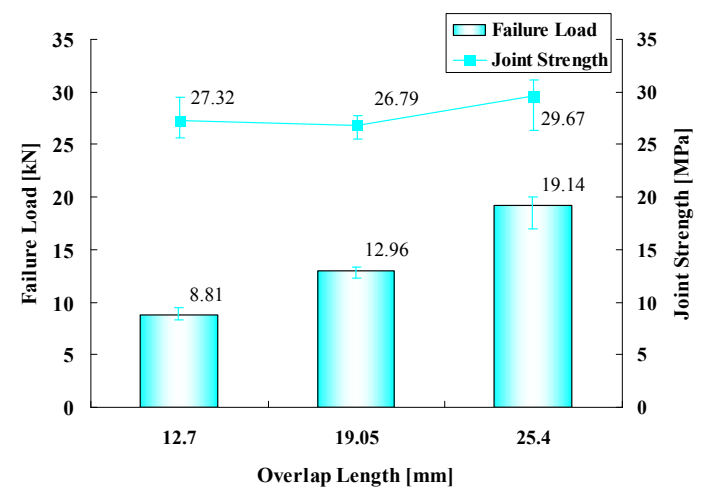

Fig. 17. Failure loads and joint strengths of hybrid joints (Laminate A)

이 $289 \mathrm{MPa}$ 인 점을 고려하면, 체결부 $\mathrm{A}$ 의 겹침 길이 $25.4 \mathrm{~mm}$ 의 경우에만 알루미늄 모재에서 항 복이 발생하는 것을 알 수 있다. 두께가 크지 않 은 알루미늄 모재를 사용한 체결부에서 겹침길이 가 커질 경우 알루미늄 모재에서 항복이 발생하 는 현상은 참고문헌 [9]에서도 실험적으로 관찰 된 바 있다.

접착과 리벳을 동시에 사용한 하이브리드 체 결부에 대한 파손하중 및 파손강도는 Fig. 17과 18 에 나타내었다. Fig. 17에서와 같이 체결부 A 의 경우 겹침길이가 증가함에 따라 파손하중이 증가함은 물론이고, 파손하중에 접착부 면적을 나눈 파손강도도 비슷하거나 증가하는 경향을 보 인다. 값으로는 겹침길이가 $12.7 \mathrm{~mm}$ 일 때 27.32 $\mathrm{MPa}, 19.05 \mathrm{~mm}$ 일 때 $26.79 \mathrm{MPa}(12.7 \mathrm{~mm}$ 대비 $2 \%$ 감소), $25.4 \mathrm{~mm}$ 일 때 $29.67 \mathrm{MPa}(12.7 \mathrm{~mm}$ 대비 $9 \%$ 증가)로 나타났다.

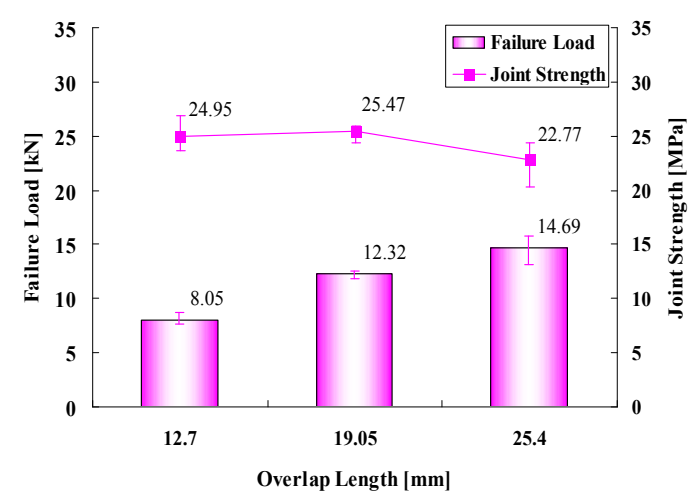

Fig. 18. Failure loads and joint strengths of hybrid joints (Laminate B)

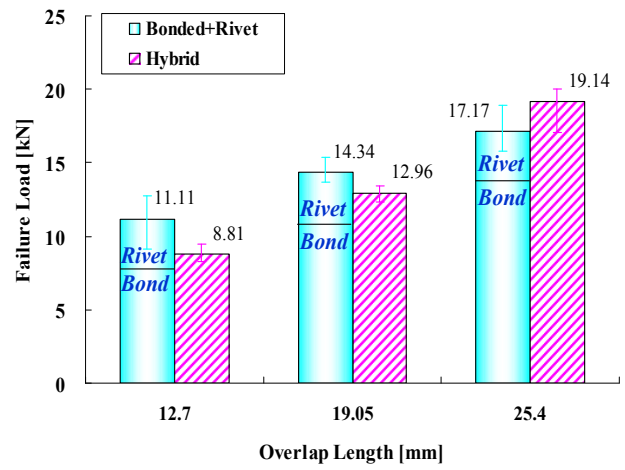

Fig. 19. Failure loads comparison (Laminate A)

Fig. 18 에 보인 체결부 $\mathrm{B}$ 의 경우, 겹침길이가 증가함에 따라 파손하중은 증가하지만, 파손강도 는 겹침길이가 $12.7,19.05,25.4 \mathrm{~mm}$ 일 때 각각 $24.95,25.47,22.77 \mathrm{MPa}$ 로 $12.7 \mathrm{~mm}$ 대비 $2 \%$ 증 가 후, $8 \%$ 낮아진다. 겹침길이가 $25.4 \mathrm{~mm}$ 인 경 우 평균값은 약간 감소하지만 데이터의 범위가 넓어 전체적으로는 겹침길이에 따른 특별한 경향 을 발견하기는 어려운 것으로 판단된다.

본 연구의 주 목표는 접착제와 리벳을 동시에 사용한 하이브리드 체결부의 체결강도가 각각을 독립적으로 사용한 경우에 비해 어떻게 달라지는 지를 체계적으로 연구하는 것이다. 이를 위해 접 착 체결부와 리벳 체결부 파손하중을 합한 값과 하이브리드 체결부의 파손하중을 Fig. 19, 20에 나타내었다. 리벳의 종류나 모재의 두께에 따라 그 값이 달라질 수 있겠지만, 본 연구에서 사용 한 체결부의 경우 리벳 체결부의 파손하중은 접 착 체결부의 파손하중에 비해 최대 $41.8 \%$, 최소 $23.6 \%$ 에 불과하며, 접착길이 즉 겹침길이가 길어 


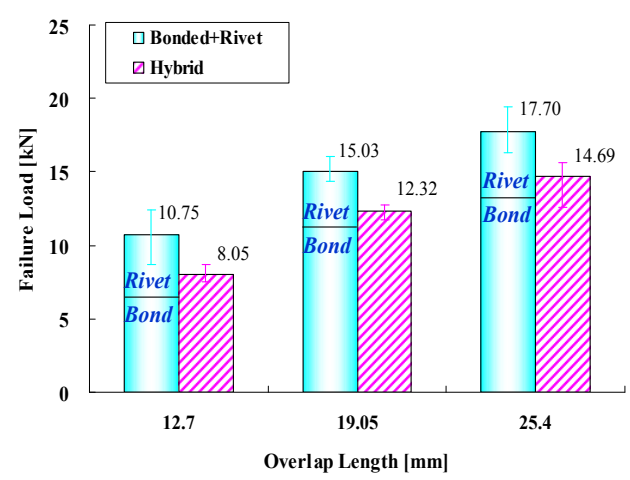

Fig. 20. Failure loads comparison (Laminate B)

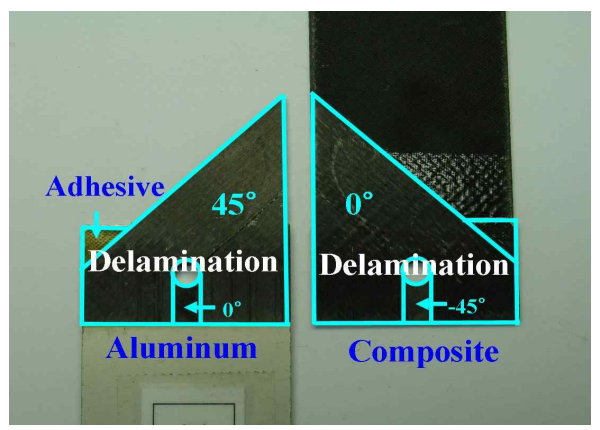

(a) Laminate $A(b=12.7 \mathrm{~mm})$

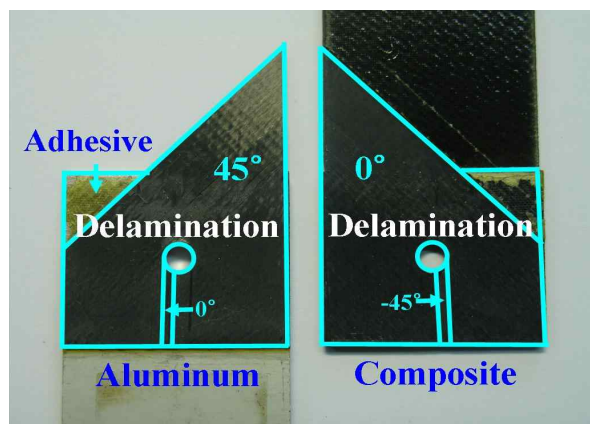

(b) Laminate A (b=19.05 mm)

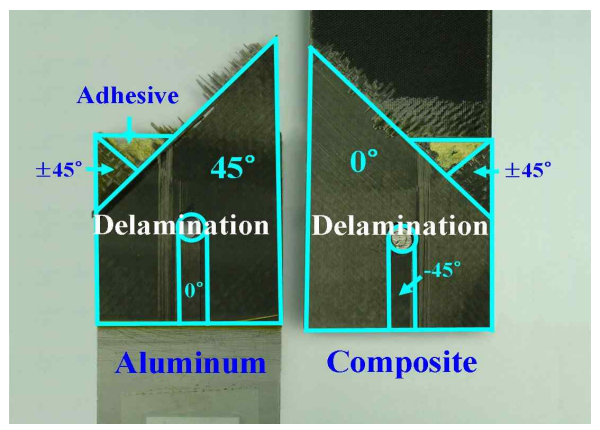

(c) Laminate A (b=25.4 mm)
질수록 접착제의 파손하중이 커진다. ASTM D5868-01에 의하면 복합재 접착 체결부 강도시 험시의 접착길이를 $25.4 \mathrm{~mm}$ 로 규정하고 있음을 참고할 때 정적 강도관점에서는 접착 체결이 리 벳에 비해 월등한 성능을 보임을 알 수 있다.

본 연구에서 고려한 모든 경우에 대하여 하이 브리드 체결부의 파손하중은 접착제만을 사용한 접착 체결부에 비해 12 39\% (A 체결부)와 $2 \%$ (B 체결부) 증가하였다. $\mathrm{A}$ 체결부의 경우 그 증가폭은 매우 큰 것으로 볼 수 있으며, 접착 제를 기계적 체결과 함께 사용할 경우 피로특성 이 향상된다[18]는 점을 고려할 때 설계자들을 위한 의미 있는 결과로 볼 수 있다.

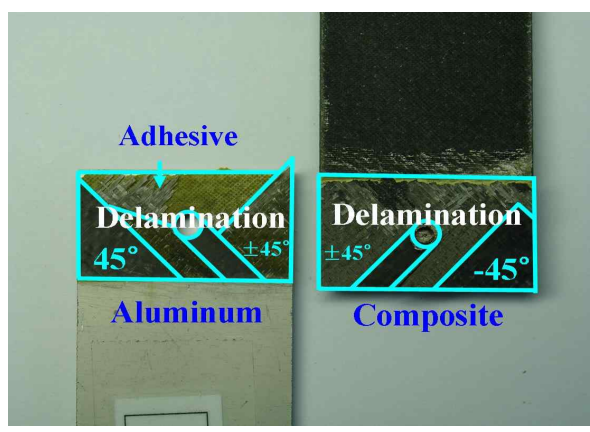

(d) Laminate $B(b=12.7 \mathrm{~mm})$

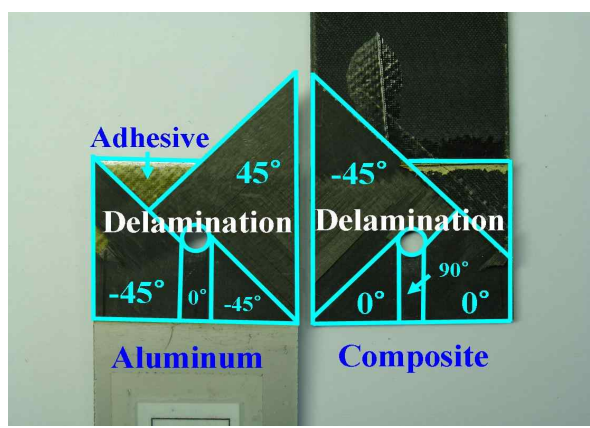

(e) Laminate B (b=19.05 mm)

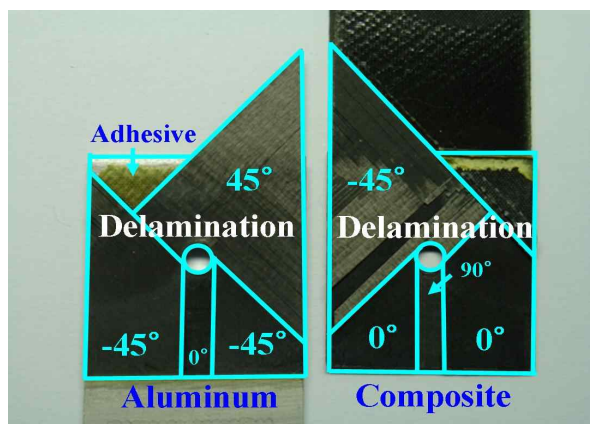

(f) Laminate $B(b=25.4 \mathrm{~mm})$

Fig. 21. Failure modes of hybrid joints 
또한 리벳과 접착제를 독립적으로 사용한 시 험에서는 적층판 즉 적층순서의 차이에 따른 파 손하중의 특별한 경향을 발견하기 어려웠다. 그 러나 하이브리드 체결부에서는 $\mathrm{A}$ 체결부의 파손 하중이 $\mathrm{B}$ 체결부에 비해 각각 $9.4,5.2,30.3 \%$ 높 게 나타나는 것을 발견하였다. 앞에서도 밝힌 바 와 같이, $\mathrm{A}$ 적층은 이웃한 층의 각도 차이를 $45^{\circ}$ 로 설정하고, $\mathrm{B}$ 적층은 대부분 $90^{\circ}$ 로 설정한 경 우로, 이웃한 층의 각도 차이가 작은 $\mathrm{A}$ 적층이 층간분리에 강할 것으로 예상하였다. 그러나 접 착제만 적용한 체결부에서는 $\mathrm{A}$ 와 $\mathrm{B}$ 적층 간에 특별한 경향성을 발견할 수 없었던 반면 하이브 리드 적층에서는 $\mathrm{A}$ 가 $\mathrm{B}$ 보다 파손에 강한 일관된 경향이 발견되었다. 원인에 대하여는 추가적인 연구가 수행되어야 할 것으로 판단된다.

Fig. 21은 겹침길이와 적층순서에 따른 하이브 리드 체결 시편의 파손면을 보인 것이다. 하이브 리드체결 시편의 최종 파손에서도 접착 체결부에 서와 마찬가지로 층간분리가 주된 파손모드를 이 루고 있다. 층간분리가 발생하는 위치도 큰 차이 가 없다. 다만 리벳에 의한 전단파손(shear-out) 이 일부 층에서 발생하고 있는 것은 단순 접착 체결부와 다른 점이다. 단순 리벳 체결의 경우 모재의 부분적 베어링을 동반한 리벳의 파손 즉 리벳 머리와 몸체의 분리가 최종파손모드였다. 그러나 하이브리드 체결에서는 최종파손까지 리 벳의 파손은 발견되지 않으며 복합재 모재의 광 범위한 층간분리 파손과 리벳에 의한 일부층의 전단파손만이 나타난다.

본 연구에서 변수로 설정하지는 않았지만 하 이브리드 체결에서 접착부 폭과 리벳의 직경비 즉 $\mathrm{w} / \mathrm{d}$ 의 비를 늘일 경우에는 접착부에 대한 리벳의 상대적 역할이 줄어들게 될 것이다. 따라 서 $\mathrm{w} / \mathrm{d}$ 의 비가 커지면 하이브리드 체결의 강도 는 접착체결의 강도에 접근해갈 것으로 추측할 수 있다.

\section{$\mathrm{IV}$. 결 론}

본 논문에서는 필름 형태의 FM73m 접착제와 NAS9308M-4-03 스테인리스강 리벳을 사용하여, 알루미늄 2024-T3와 USN125 탄소/에폭시 복합 재 단일겹침 하이브리드 체결부의 강도를 실험으 로 연구하였다. 전체적으로 접착제만를 사용한 체결부의 강도가 리벳만을 사용한 경우에 비해 1.4 배에서 3.2 배까지 높게 나타났다. 하이브리드 체결부의 강도는 접착제만을 사용한 체결부에 비 해 최대 $39 \%$ 까지 높게 나타났다. 또한 인접한
층의 적층각 차이를 $45^{\circ}$ 로 설정한 $\mathrm{A}$ 체결부가 $90^{\circ}$ 로 설정한 $\mathrm{B}$ 체결부에 비해 최대 $30 \%$ 까지 높 은 파손하중을 보였다. 하이브리드 체결부의 최 종파손은 부분적인 전단파손을 동반한 층간분리 의 형태로 나타났고, 리벳의 파손은 발견되지 않 았다.

\section{후 기}

본 연구는 한국학술진흥재단(중점연구소지원사 업(KRF-2005-005-J09902))과 경상대학교 항공기부 품기술연구소의 지원으로 수행된 것이며 이에 감 사드립니다.

\section{참고문헌}

1) Baker A., Dutton S., and Kelly D., Composite Materials for Aircraft Structures, AIAA Education Series, 2004

2) Kweon, J. H., Ahn, H. S., and Choi, J. H., "A New Method to Determine the Characteristic Lengths of Composite Joints without Testing", Composite Structures, Vol. 66, No. 1/4, 2004, pp. 303 315.

3) Riccio, A., and Marciano, L., "Effects of Geometrical and Material Features on Damage Onset and Propagation in Single-lap Bolted Composite Joints under Tensile Load : Part I - Experimental Studies", Journal of Composite Materials, Vol. 39, No. 23, 2005, pp. 2071 2090.

4) Mccarthy, M. A., Lawlor, V. P., and Stanley, W. F., "An Experimental Study of Bolt-Hole Clearance Effects in Single-lap, Multibolt Composite Joints", Journal of Composite Materials, Vol. 39, No. 9, 2005, pp. 799 825 .

5) Lawlor, V. P., Mccarthy, M. A., and Stanley, W. F., "An Experimental Study of Bolt-Hole Clearance Effects in Double-lap, Multibolt Composite Joints", Composite Structures, Vol. 71, No. 2, 2005, pp. 176 190.

6) Xiao, Y., and Ishikawa, T., "Bearing Strength and Failure Behaviro of Bolted Composite Joints (part I : Experimental Investigation)", Composite Science and Technology, Vol. 65, No. 7/8, 2005, pp. 1022 1031 .

7) Okutan, B., and Karakuzu, R., "The 
Strength of Pinned Joints in Laminated Composite", Composite Science and Technology, Vol. 63, No. 6, 2003, pp. 893 905.

8) Pierron, F., and Cerisier, F., "A Numerical and Experimental Study of Woven Composite Pin-Joints," Journal of Composite Materials, Vol. 34, No. 12, 2000, pp. 1028 1054.

9) 김태환, 성명수, 권진회, 최진호, "탄소 복합 재-알루미늄 단일겹침 접착 체결부의 강도에 관 한 인자연구", 한국복합재료학회지, 제 20 권 제 5 호, 2007, pp. 34 42

10) Kim, K. S., Yoo, J. S., Yi, Y. M., and Kim, C. G., "Failure Mode and Strength of Uni-directional Composite Single Lap Bonded Joints with Different Bonding Methods", Composite Structures, Vol. 72, No. 4, 2006, pp. $477 \sim 485$.

11) Quaresimin, M., and Ricotta, M., "Fatigue Behaviour and Damage Evolution of Single Lap Bonded Joints in Composite Material", Composite Science and Technology, Vol. 66, No. 2, 2006, pp. $176 \sim 187$.

12) Owens, J. F. P., and Lee-Sullivan, P., "Stiffness Behaviour due to Fracture in Adhesively Bonded Composite-to-Aluminum Joints I . Theoretical Model", International Journal of Adhesion \& Adhesive", Vol. 20, No. 1, 2000, pp. 39 45.

13) Owens, J. F. P., and Lee-Sullivan, P., "Stiffness Behaviour due to Fracture in Adhesively Bonded Composite-to-Aluminum
Joints II. Experimental", International Journal of Adhesion \& Adhesive", Vol. 20, No. 1, 2000, pp. $47 \sim 58$.

14) Li, G., Pang, S. S., Woldesenbet, E., Stubblefield, M. A., Mensah, P. F., and Ibekwe, S. I., "Investigation of Prepreg Bonded Composite Single Lap Joints", Composite Part B : engineering, Vol. 32, No. 8, 2001, pp. 651 658.

15) Shin, K. C., and Lee, J. J., "Bond Parameters to Improve Tensile Load Bearing Capacities of $\mathrm{Co}^{-}$cured Single and Double Lap Joints with Steel and Carbon Fiber-epoxy Composite Adherends", Journal of Composite Materials, Vol. 37, No. 5, 2003, pp. 401 420.

16) Kweon, J. H., Jung, J. W., Kim, T. H., Choi, J. H., and Kim, D. H., "Failure of Carbon Composite-to-Aluminum Joints with Combined Mechanical Fastening and Adhesive Bonding", Composite Structures, Vol. 75, No. 1/4, 2006, pp. 192 198.

17) Kelly, G., "Load Transfer in Hybrid (Bond/Bolted) Composite Single-lap Joints", Composite Structures, Vol. 69, No. 1, 2005, pp. $35 \sim 43$.

18) Kelly, G., "Quasi-static Strength and Fatigue Life of Hybrid (Bond/Bolted) Composite Single-lap Joints", Composite Structures, Vol. 72, No. 1, 2006, pp. 112 129.

19) FM73 Toughened Epoxy Film, Manufacturer's Data Sheet, Cytec Engineering Materials Ltd. 